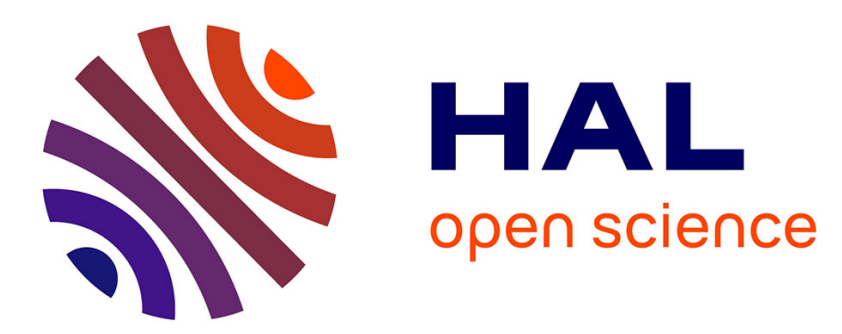

\title{
Iron Transport and Magnetite Crystal Formation of the Magnetic Bacterium Magnetospirillum gryphiswaldense
}

\author{
D. Schüler, E. Baeuerlein
}

\section{To cite this version:}

D. Schüler, E. Baeuerlein. Iron Transport and Magnetite Crystal Formation of the Magnetic Bacterium Magnetospirillum gryphiswaldense. Journal de Physique IV Proceedings, 1997, 07 (C1), pp.C1-647C1-650. 10.1051/jp4:19971267 . jpa-00254977

\section{HAL Id: jpa-00254977 https://hal.science/jpa-00254977}

Submitted on 1 Jan 1997

HAL is a multi-disciplinary open access archive for the deposit and dissemination of scientific research documents, whether they are published or not. The documents may come from teaching and research institutions in France or abroad, or from public or private research centers.
L'archive ouverte pluridisciplinaire HAL, est destinée au dépôt et à la diffusion de documents scientifiques de niveau recherche, publiés ou non, émanant des établissements d'enseignement et de recherche français ou étrangers, des laboratoires publics ou privés. 


\title{
Iron Transport and Magnetite Crystal Formation of the Magnetic Bacterium Magnetospirillum gryphiswaldense
}

\author{
D. Schüler and E. Baeuerlein \\ Max-Planck-Institut fuer Biochemie, 82152 Martinsried, Germany
}

\begin{abstract}
Magnetic bacteria are found in various morphologies as cocci, vibrios, spirilli and rods in aquatic mud layers. Magnetite $\left(\mathrm{Fe}_{3} \mathrm{O}_{4}\right)$ is stored in phospholipid vesicles as bullet-shaped, hexagonal or cubooctahydral crystals. Size and form of these crystals are species-specific and precisely controlled. The microaerophilic Magnetospirillum gryphiswaldense forms in a near to linear chain up to 60 cubooctahedral, single domain magnetite crystals of $42-45 \mathrm{~nm}$ diameter, which generates a magnetic dipole. Six proteins were detected in SDS-gels of the special phospholipid vesicles, which envelope the magnetite crystals. These proteins are probably involved in iron transport (FeII or/and FeIII), in nucleation catalysis, in redox or/and $\mathrm{pH}$ control.

Iron uptake and dynamics of magnetite crystal formation were estimated simultaneously by change of light scattering of the cells within homogeneous magnetic fields. A very efficient, energy-dependent uptake of FeIII in presence of spent, iron-deficient growth medium was found. Iron uptake was tightly coupled to magnetite crystal formation and magnetisation. When FeIII was added to iron-starved cells under inducing conditions, FeIII was immediately transported into the cells and superparamagnetic crystals of less than $20 \mathrm{~nm}$ were formed first within $30 \mathrm{~min}$.
\end{abstract}

\section{INTRODUCTION}

Biomineralization, the ability of organisms to form inorganic materials, is widely distributed and occurs in almost every phylum [1-3]. Bacteria possess surfaces that may interact strongly with metal ions. They are able to extract toxic heavy metals from the natural freshwater environments and to immobilize them there. Acidic groups on the surface apparently nucleate the formation of amorphous precipitates which grow and may become crystalline [4]. Some bacteria can directly oxidize even aromatic compounds to carbon dioxide by reduction of FeIII. Such dissimilatory FeIII-reducing microorganisms form magnetite as an extracellular endproduct. These magnetite crystals are round or oval and $10-50 \mathrm{~nm}$ in diameter, but $96 \%$ of them are superparamagnetic. There is no evidence of cellular material enveloping the crystals [5].

Magnetic bacteria were discovered and first described 20 years ago [6]. They may orient themselves and migrate along magnetic field lines. This is possible because magnetic crystals of magnetite $\left(\mathrm{Fe}_{3} \mathrm{O}_{4}\right)$ are present in the cell. Each single crystal is enveloped by a membrane, an entity which is called magnetosome. The biological function of cellular magnetism is still an open question, but some magnetic bacteria may use a magnetonavigation by interaction with the Earth's magnetic field [1].

\subsection{Results and Discussion}

\subsubsection{Variety of morphologies}

Magnetic bacteria are apparently ubiquitous. We found an impressive variety of morphologies as cocci, vibrios, spirilli and rods in mud layers of the Bavarian lake Chiemsee and the firepond of our institute in Martinsried. At least 14 different forms could be distinguished. Magnetic cocci were observed in large numbers and were found to be the dominant organisms in the majority of samples. Magnetic rods and vibrios were usually found in lower numbers, but the range of species and their relative abundances considerably varied depending on sampling site. Remarkably, some magnetic bacteria of unusual large size $(10-15 \mu \mathrm{m})$ were detected, which contained up to 1000 discrete magnetic crystals. 

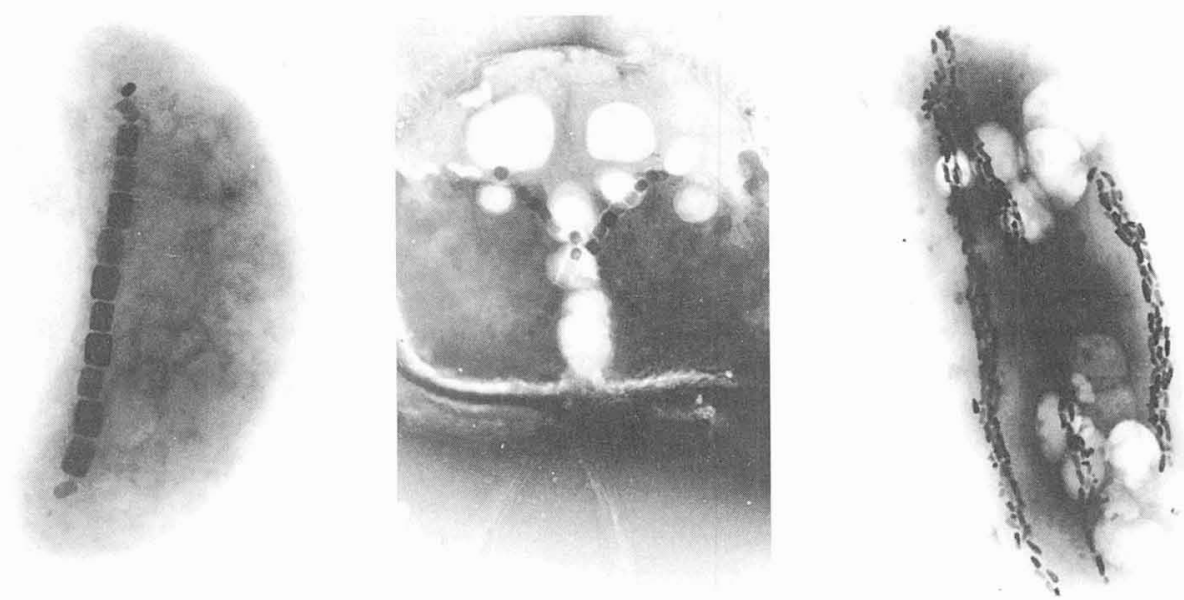

Figure 1: Various magnetic bacteria from the mud layer in $10 \mathrm{~m}$ depth of the Bavarian lake „Chiemsee“ with different magnetic crystals.

1) left: Vibrio $(1.6 \times 0.6 \mu \mathrm{m})$ with a chain of 13 hexagonal crystals $(140 \times 70 \mathrm{~nm}) ; 2)$ middle:Coccus $(02.9 \mu \mathrm{m})$ with two crossed chains of 28 hexagonal crystals $(120 \times 85 \mathrm{~nm}) ; 3)$ right: $\operatorname{Rod}(9 \times 1.4 \mu \mathrm{m})$ with bundles of chains of 300 bullet-shaped crystals $(120 \times 45 \mathrm{~nm})$.

Low-magnification electron micrographs of bacterial magnetosome indicated a variety of morphological forms which were species-specific. Viewed in projection, cubic, rectangular, hexagonal and bullet-shaped particles have been observed. Magnetic crystals prevalently were in the size of 40-120 nm. In most cells, magnetosomes were arranged in one short chain. Some bacteria were found to contain two or more parallel or crossing chains, whereas in some species an irregular arrangement in a rather loose clump was observed. Nevertheless, these latter organisms still retained a net dipole magnetic dipole.

\subsubsection{Isolation of a pure culture: Magnetospirillum gryphiswaldense}

Magnetic separation techniques were used to isolate various magnetic bacteria. A pure culture of a spirillum, Magnetospirillum gryphiswaldense could be obtained [7]. This organism proved to be a new magnetic bacterium and was described as Magnetospirillum gryphiswaldense MSR-1, representing the type strain of the proposed genus Magnetospirillum [8]. M. gryphiswaldense belongs to the $\alpha$-subgroup of proteobacteria and is able to form intracellularly up to 60 magnetic particles, which are arranged in a chain. The cells are very motile by means of a single flagellum at each pole. Under microaerobic conditions, $M$. gryhiswaldense can be grown in a simple liquid medium containing organic acids and mineral salts. A special method was developed for the mass cultivation of magnetic cells up to the 100-1-scale [9]. Among the magnetic bacteria available in pure culture, $M$. gryphiswaldense is the organism which can be grown best in the laboratory with a yield of $33 \mathrm{~g}$ dry weight per $1001 \mathrm{medium}$. Thus, one main limitation associated with the research in the field of bacterial magnetite biomineralization could be overcome.

\subsubsection{Iron metabolism in M. gryphiswaldense}

Magnetic bacteria need iron not only as an essential element for bacterial growth, i.e. biosynthesis of various iron metalloproteins, but use it also to form inorganic crystals in vesicles, called magnetosomes. The iron content of magnetic bacteria may exceed $2 \%$ of dry weight $[10,11]$, compared to that of $E$. coli, which is found with 0.005 $0.022 \%$ of dry weight $[12,13]$. But iron uptake is poorly investigated until now and an exact mechanism remains to be studied in detail.

Growth and magnetite formation in Magnetospirillum gryphiswaldense MSR-1 were found close to the maximum at extracellular iron concentration of $15-20 \mu \mathrm{M}$. The uptake of iron was studied by detection of incorporation of radioactive ${ }^{55} \mathrm{Fe}$. Ferric iron was taken up at high rate. Spent culture fluids stimulated the uptake of ferric iron in irondepleted cells, whereas fresh medium and transport buffer were unable herein. Several iron chelators including various microbial siderophores failed to promote transport of iron into the cells. Moreover, no siderophore-like compounds could be detected in spent culture fluids by CAS-assay, which is reported to be an universal tool for 
detection of siderophores [14]. Ferric iron uptake obeyed Michaelis-Menten-Kinetics with a $K_{M}$ of $3 \mu M$ and a $V_{\max }$ of $0.86 \mathrm{nmol} / \mathrm{min} \times \mathrm{mg}$ dry weight, suggesting a comparatively low-affinity, but extraordinarily high-velocity transport system [15]. The maximum uptake rate was found to more then ten times higher then usually observed in other heterotrophic bacteria under comparable conditions. Iron incorporation was sensitive to uncouplers DNP and CCCP indicating an energay-dependent transport process [10].

\subsubsection{Assaying magnetite formation by a simple light scattering method}

A fast and sensitive tool for monitoring the magnetite formation in growing cultures of $M$. grsphiswaldense was developed. Cells are aligned parallel to the field lines in a magnetic field, resulting in a change of light scattering. The ratio of scattering intensities $\left(\mathrm{C}_{\text {mag }}\right)$ at different angles of magnetic field, relative to the light beam, was used to characterize the average magnetic orientation of the cells. $C_{\text {mag }}$ was found to be well correlated to the average number of particles in different magnetic cell populations. Thus, estimation of magnetosomes content can be made, using magnetically induced differential light scattering [16].

\subsubsection{Dynamics of magnetite biomineralisation in M. gryphiswaldense}

Growth, magnetism and dissolved oxygen concentration were followed simultaneously in aerobic cultures of $M$. gryphiswaldense at constant aeration, to determine optimal conditions for bacterial magnetite crystal formation. Magnetite formation was found to follow characteristic dynamics throughout the growth phase. In early stage of growth, cell density and thus, oxygen consumption by cells were comparatively low resulting in a high concentration of dissolved oxygen. Under these conditions, cells were lacking magnetite particles. With proceeding growth, oxygen was increasingly consumed by respiration of cells causing a drop of dissolved oxygen. If microaerobic conditions became established with oxygen concentration, falling below a critical value of about $3 \%$ saturation, magnetite biomineralization was initiated and cells started to form magnetite crystals within a few hours, as indicated by a detectable change in differential light scattering.

The extraordinary uptake of iron required for formation of $\mathrm{Fe}_{3} \mathrm{O}_{4}$ was found to be tightly coupled to the initiation of magnetite biomineralization. Iron was not taken up continuously throughout the growth, but iron uptake and magnetite formation occurred simultaneously only at microaerobic conditions $[17,18]$.

\subsubsection{The magnetite crystal and ist enveloping membrane, an entity called magnetosome}

We succeeded in cultivating $M$. gryphiswaldense in large scale. The high yield of $33 \mathrm{~g}$ dry weight of bacteria from a 1001 fermenter was the prerequisite for the preparation of magnetosomes, enough for their purification which allowed to distinguish between proteins of the magnetosome membrane and contaminations form other membranes. A new method was developed for the purification of magnetosomes, which were collected from disrupted cells by density gradient centrifugation and then applied to a magnetic separation column. After several washings about 300 $\mathrm{mg}$ magnetosomes of high purity were obtained from $33 \mathrm{~g}$ dry weight of bacteria. The magnetite in magnetosomes of M. gryphiswaldense forms cubooctahedral, single domain crystals, which are $42-45 \mathrm{~nm}$ in diameter. Analysis by energy-dispersive $\mathrm{X}$-ray analysis and atomic absorption revealed that these crystals are composed exclusively by iron and oxygen. Any attempt to biosynthesize magnetic iron spinels, $\mathrm{Fe}_{3 * x} \mathrm{M}_{\mathrm{x}} \mathrm{O}_{4}$ instead of magnetite, $\mathrm{Fe}_{3} \mathrm{O}_{4}$, within $M$. gryphiswaldense by incubating cells under different conditions at variable concentrations of copper, cobalt, chranium, nickel, manganese and titanium, failed so far.

In electron micrographs the individual crystals appear to be enclosed by a membrane. It is remarkable that these isolated magnetosome chains do not collapse in suspension, but show a certain repulsion, probably an electrostatic one. When treated with detergents these membranes are apparently dissolved and magnetite crystals agglomerate. In this extract, at least six magnetosome-associated proteins were detected, which are specific for the magnetosome membrane.

But not only the protein compositions of outer, inner and magnetosome membrane are different, but also the compositions of their phospholipids. In addition an unknown hydrophobic compound, probably a lipid, was found in preparation of the outer and cytoplasmic, but not of the magnetosome membrane. This marker substance was the analytical key in isolating magnetosomes without contamination of the other membranes.

\subsubsection{Magnetonavigation.}

In all magnetic bacteria, we had found, is the magnetic dipole parallel to the axis of motility, even if the magnetite crystals appeared to be randomly distributed close to the flagellar motor. In the original interpretation of magnetic behaviour, what was called „magnetotaxis", [6] it was assumed that magnetic bacteria orient themselves along the Earth's magnetic field like a magnetic needle and that in an active process they follow the gradient of oxygen 
concentration, i.e. aerotaxis, with their flagellar motor for microaerophilic conditions, the preferred environment. But this way of "magnetotaxis" appears to be an open question, because $M$. gryphiswaldense needs these precise microaerophilic conditions for magnetic crystal formation, the prerequisite of this magnetotaxis. $M$. gryphiswaldense swims fast, $40 \mu \mathrm{m} / \mathrm{sec}$ and appears to synthesize like Wolinella succinogenes $[19,20,21]$ an extended basal disk, an archimedic spiral of close to 2200 subunits of a $20 \mathrm{kDa}$ protein with an average diameter of $180 \mathrm{~nm}$. A bushing of the flagellar motors, the L-P ring complex is inserted into the center of the basal disk.

It was found recently that Vibrio alginolyticus, a marine bacterium with $\mathrm{Na}^{+}$-driven polar flagellar motor, rotates very fast between 1100-1700 r.p.s. with an average swimming speed of $160 \mu \mathrm{m} \mathrm{x} \mathrm{s}{ }^{-1}$. This suggests that fast rotating flagellar motors are essentially located at the poles of bacteria for stabilization [22]. In addition marine bacteria were reported to form microswarms which are able to accelerate up to $1450 \mu \mathrm{m} \mathrm{x} \mathrm{s}^{-2}$ to a mean speed of $230 \mu \mathrm{m} \mathrm{x} \mathrm{s}{ }^{-1}$ [23]. Those high speeds and quick shifts may reflect the requirement for useful motility in a turbulent ocean [24]. The oxicanoxic transition zone in aquatic muds may apparently migrate up to four meters high from the bottom of a lake or the sea [25], where magnetic bacteria were found to concentrate or comigrate. These experiences allow to speculate in a modified way on magnetonavigation. When a turbulent ocean destroys this oxic-anoxic zone, magnetic bacteria may orient and move with high speed to microaerophilic environments [26].

\section{References}

[1] Frankel, R.B. in „Iron Biominerals“. R.B. Frankel and R.P. Blakemore Eds. (Plenum Press, New York, 1991) pp. $1-6$.

[2] Kirschvink, I.L., Bioelectromagnetics 10 (1989) 239-259.

[3] Lowenstam, H.A., Science 211 (1981) 1126-1131.

[4] Beveridge, T.J., S. Schultze-Lam and J.B. Thompson in „Metal Speciation and Contamination of Soil“. H.E. Allen et al. Eds. (Lewis Publishers, Boca Raton, 1995) pp. 183-205.

[5] Lovely, D.R. in „Iron Biominerais“. R.B. Frankel and R.P. Blakemore Eds. (Plenum Press, New York, 1991) pp. 151-166.

[6] Blakemore, R.P, Ann. Rev. Microbiol. 36 (1982) 217-238

[7] Schüler, D., Diploma work, University Greifswald, Germany, 1990.

[8] Schleifer, K.H., Schüler, D., Spring, S. Weizenegger, M., Amann, R., Ludwig, W. and Köhler, M., System. Appl. Microbiol. 14 (1991) 379-385.

[9] Schüler, D., dissertation work. Technical University, Munich, 1994.

[10] Schüler, D. and Baeuerlein, E. 1996. Submitted for publication.

[11] Blakemore, R.P., Maratea, D. and Wolfe, R.S., J. Bacteriol. 140 (1979) 720-729.

[12] Hartmann, A. and Braun, V., J. Bacteriol. 143 (1980) 246-255.

[13] Matzanke, B.F., Müller, G.I., Bill, E. and Trautwein, A.X., Eur. J. Biochem. 183 (1989) 371-379.

[14] Schwyn, B. and Neilands, J.B., Analyt. Biochem. 160 (1987) 57-64.

[15] Winkelmann, G. Specificity of iron transport in bacteria and fungi in: Winkelmann, G., ed. CRC Handbook of microbial iron chelates. CRC Press, 1991, p. 65-106.

[16] Schüler, D., Uhl, R. and Baeuerlein, E., FEMS Microbiol. Lett. 132 (1995) 139-145.

[17] Schüler, D. and Baeuerlein, E. 1996. Submitted for publication..

[18] Schüler, D. and Baeuerlein, E. (1996) „Iron Uptake and Magnetite Biomineralization in the Magnetic Freshwater Bacterium Magnetospirillum gryphiswaldense“ in FASEB Workshop on "Biomineralization and Nanofabrication" May 23-25, San Luis Obispo, Ca. Abst. 5

[19] Schuster, S.C. and Baeuerlein, E. 1992. J. Bacteriol. 174 (1992) 263-268.

[20] Engelhardt, H., Schuster, S.C. and Baeuerlein, E. Science 262 (1993) 1046-1048.

[21] Stahlberg, A., Schuster, S.C., Bauer, M. Baeuerlein, E., Zao, R., Reese, T.S. and Khan, S. Biophys. J. 68 (1995) $168 \mathrm{~s}-172 \mathrm{~s}$.

[22] Magariyama, Y., Sugiyama, S., Muramoto, K., Maekawa, Y., Kawagishi, I., Imae, Y. and Kudo, S. Nature 371 (1994) 752.

[23] Mitchell, J.G., Pearson, L., Dillon, S. and Kantalis, K. Appl. Environ. Microbiol. 61 (1995) 4436-4440.

[24] Mitchell, J.G., Pearson, L., Bonazinga, A., Dillon, S., Khouri, H. and Paxinos, R. Appl. Environ. Microbiol. 61 (1995) 877-882.

[25] Frankel, R.B. and D.A. Bazylinski. Hyperfine Interactions 90 (1994) 135-142.

[26] Baeuerlein, E., Schüler, D., Stahlberg, A. and Gassmann, M. (1996). „Magnetosome Chains and Flagellar Motors: Two Bacterial Nanotechnologies" in FASEB Workshop on "Biomineralization and Nanofabrication" May 23-25, San Luis Obispo, CA. Abst. 7. 